\title{
The infra-value of human rights in the context of assisted reproduction regulation in México
}

\author{
Rosa Verónica Esparza-Pérez \\ Doctoral student, Universidad Nacional de Educación a Distancia, Madrid, Spain
}

\begin{abstract}
Infertility represents a problem in the context of reproductive health; to treat it were developed the techniques of assisted human reproduction, despite medical advances, the practice of techniques is subject to medical, legal and ethical dysfunctions. In Mexico, since the late 1980s assisted reproduction clinics were set up in public and private sector hospitals; however, they do not yet have a legal framework to regulate them in a specific way, which causes human rights violations that could be avoided with adequate regulation. This article advances the need to provide Mexico with such regulation as a means of guaranteeing both human rights and the rights of physicians and other health workers involved in these techniques.
\end{abstract}

KEY WORDS: Human reproductive techniques. México. Human rights. Informed consent.

\section{Introduction}

The World Health Organization (WHO) defines infertility as the result of 2 years of exposure to the risk of pregnancy without conceiving. David Adamson, member of the WHO, proposed the International Committee for Monitoring Assisted Reproductive Technologies to modify the definition of infertility. In Adamson's words: "The definition of infertility includes the rights of all individuals to have a family, and that includes single men, single women, gay men, gay women. It puts a stake in the ground and says an individual has got a right to reproduce whether or not they have a partner"'.

Infertility represents a problem in the context of reproductive health. Infertility rates are variable, and epidemiological studies refer they range between 14 and $16 \%^{2}$. Hence, in the last quarter of the $20^{\text {th }}$ century, human assisted reproduction techniques (HART) were developed aiming to treat infertility, as well as to prevent and address genetic or hereditary-origin conditions. In spite of medical advances, the practice of HART is subject to medical, legal and ethical contingencies.

\section{Human assisted reproduction techniques regulatory framework in Mexico}

In 1949, a group of gynecologists, andrologists, endocrinologists and investigators founded the Mexican Association for the Study of Sterility, with the purpose to study the problems of sterility and infertility and to diffuse knowledge on the subject. In order to reach its goal, the association proposed, among other measures, the creation of sterility-specialized clinics. Some relevant medical professionals were part of their directive boards; that was the case of Alfonso Álvarez Bravo, Luis Castelazo Ayala, Francisco Durazo Quiroz, Juan Ramón Argüelles, Javier Soberón Acevedo and Javier Santos González, just to mention a few ${ }^{3}$. It was by the end of the 1980 decade that assisted reproduction clinics were created in public and private hospitals"; however, currently, there isn't any legal framework that specifically regulates them.

The first initiative on the subject was presented in the bosom of the Legislative Power in 1999; although to date no project has been approved. This gives a
Gac Med Mex. 2017;153:570-575

Contents available at PubMed www.gacetamedicademexico.com 
clue about the degree of complexity its regulation has. In November 2016, the Senate approved two drafts: one regulating HART and the other gestational surrogacy, but still they have to be voted by the House of Representatives. However, we consider it necessary for these drafts to be reviewed, since both contain regulations that might generate certain infringement of people's rights, should they be approved ${ }^{5}$. Definitive approval shall be awaited in order to make a comprehensive analysis of such legislation.

As pointed out in other compared legislations, HART complexity and specialization should only be addressed by trained professionals in establishments that require specific infrastructure, equipment, instruments and supplies. Only so can people's health be ensured, as well as the responsible practice of healthcare professionals who participate in these treatments. In Mexico, is corresponds to the Federal Commission for Protection Against Healthcare Hazards (Cofepris - Comisión Federal para la Protección contra Riesgos Sanitarios) regulating the functioning of public and private establishments where these procedures are practiced; according to Cofepris data, there are so far 89 centers authorized to practice HART ${ }^{6}$.

Public establishments that have regulatory approval to practice HART are Centro Médico Nacional (CMN) 20 de Noviembre, from the Institute of Security and Social Services of State Workers (ISSSTE - Instituto de Seguridad y Servicios Sociales de los Trabajadores del Estado); the Maternal Perinatal Hospital Mónica Pretelini, which belongs to the Institute of Health of the State of Mexico; and the Mexican Institute of Infertility, in Jalisco. The National Institute of Perinatology Isidro Espinoza de los Reyes (INper) also has an assisted reproduction unit with a sanitary license issued by the Sub-secretary of Regulation and Health Promotion of the General Directorate of Health Services Regulation to operate as a Tertiary Care Specialty Hospital of the Public Sector and to have germ cells available for assisted reproduction?

\section{Human assisted reproduction programs in public institutions}

Most public health institutes of Mexico treat infertility problems by means of low-complexity procedures -ovulation induction and ovarian hyper-stimulation with programmed intercourse-. To refer some figures, at the Mexican Institute of Social Security, between 45 and 60 low-complexity procedures are practiced monthly ${ }^{8}$; and at the Pemex High-SPECIALTY South
Central Hospital ${ }^{9}, 467$ low-complexity treatments were performed from 2006 to 2015. Even when the Pemex hospital lacks an assisted reproduction program, should there be any candidates to high-complexity techniques, the cases would be assessed for referral to a provider of services that is contracted through a process of public tender (from 2006 to 2013,487 patients were referred to contracted services).

Currently, the public institutions that perform the highest number of assisted reproduction procedures annually are INper and CMN 20 de Noviembre. From 2006 to 2015, INper performed 2120 low-complexity and 2308 high-complexity procedures ${ }^{10}$. From 2006 to 2015 , 523 low-complexity and 1043 high-complexity procedures were performed at CMN 20 de Noviembre.

\section{INper and CMN 20 de Noviembre human assisted reproduction programs admission criteria $^{13}$}

With no doubt, access to human assisted reproduction involves the exercise of different human rights, including health protection, reproductive autonomy, non-discrimination, the right to found a family and to benefit of scientific advances, with all of these rights being recognized by the Political Constitution of the Mexican United States and by international treatises that Mexico has ratified.

At the international level, the Inter-American Court of Human Rights issued a sentence on the Atravia Murillo y otros vs. Costa Rica case ${ }^{14}$. In this trial, the Court considered that the prohibition to practice the in vitro fertilization (IVF) technique in Costa Rica constituted an arbitrary interference in the rights to a private and familiar life, to build a family and to equality of people with infertility problems, since the State denied them access to a treatment that would have allowed them to overcome their situation of disadvantage as regards the possibility of having biological offspring. The Court resolved that Costa Rica should adopt measures to invalidate that prohibition and include it in its infertility programs, in accordance with the duty of guarantee with respect to the principle of non-discrimination.

Table 1 shows a comparison of the admission criteria to human assisted reproduction programs established at INper and CMN 20 de Noviembre, to immediately make observations about them.

Both INper and CMN 20 de Noviembre establish having a certain age as an admission criterion, which might be interpreted in certain cases as a violation of 
Table 1. INper and CMN 20 de Noviembre assisted reproduction programs admission criteria

\begin{tabular}{|c|c|}
\hline $\begin{array}{l}\text { INper } \\
\text { Age } \\
\text {-Women: } 35 \text { years } \\
\text {-Men: } 55 \text { years } \\
\text { Marital status } \\
\text {-Marriage or marital status certificate } \\
\text { Health } \\
\text {-Sexual life for } 1 \text { year or more without contraception and } \\
\text { having failed to achieve pregnancy } \\
\text { - Having previous study indicating sterility and undergo } \\
\text { tests to support the sterility diagnosis } \\
\text {-Cases where the partner has azoospermia (lack of } \\
\text { spermatozoids) will not be able to be attended to at the } \\
\text { institute } \\
\text { Previous children } \\
\text {-No indications are given }\end{array}$ & $\begin{array}{l}\text { CMN } 20 \text { de Noviembre } \\
\text { Age } \\
\text {-Women: } 35 \text { years } \\
\text {-Men: } 55 \text { years } \\
\text { Marital status } \\
\text {-Legally constituted couples (provide marriage or civil union certificate) } \\
\text { Health } \\
\text {-Patients without genetic anomalies susceptible to be inherited by their } \\
\text { children } \\
\text {-The partner should not have any concomitant condition, a pre-conception } \\
\text { assessment will be made to assess potential risk of pregnancy } \\
\text {-Patients with body mass index<30; in case it is higher, the patient will be } \\
\text { referred to the obesity and infertility program and once excessive weight } \\
\text { is lost, will be admitted to the infertility in the couple program } \\
\text { Previous children } \\
\text {-One child or none } \\
\text { In case all these requirements are met, infertility-causing factors are } \\
\text { evaluated and, if maternity is contraindicated, the patient will be referred } \\
\text { back to her assigned unit. }\end{array}$ \\
\hline
\end{tabular}

the equality and non-discrimination principle foreseen in article 1 of the Political Constitution of the Mexican United Stated, which prohibits discrimination for reasons of age. In this sense, we can refer that, recently, a district judge declared unconstitutional the ISSSTE criterion that restricts the assisted reproduction technique to women older than 35 years, and considered the rights to private life, to found a family and to health to be transgressed with regard to access to the technology required to exercise said rights ${ }^{15}$. The judge that resolved the issue considered that, although ISSSTE cannot repair the absence of federal regulation in matters of reproductive health, the criterion of denying this type of services to women older than 35 years violates human rights.

About the same criterion, in 2014, the National Commission of Human Rights ${ }^{16}$ admitted a complaint owing to the denial to perform an assisted reproduction procedure in a patient who was older than 35 years. The authority that was pointed at as responsible was the ISSSTE, and the issue was concluded as solved during the administrative procedure, since the authority approved for the treatment required by the complainant to be performed.

On the other hand, as regards the criterion that, to be admitted, couples had to be married or be a legally-constituted couple, violates the right to non discrimination motivated by people's marital status, in terms of what article 1 of our Constitution and several international treatises the Mexican State is committed to establish, inasmuch as this admission criterion excludes people who want to conceive as single parents, as well as couples of the same gender, by means of assisted reproduction techniques. It would appear that couples of the same gender demonstrating their marital status with a marriage certificate ${ }^{17}$ should be admitted to assisted reproduction programs, but both institutions also require for the partner to be infertile, a criterion that would not be met by a homosexual couple.

Mary Warnock points out, regarding the case of homosexuals requesting assistance for reproduction, that although there is no positive law granting people the right to have children, there is neither a law prohibiting homosexuals having them, and adds that if they are automatically rejected by fertility clinics, they will still proceed on their own. And this is a path that will inevitably make for this practice to remain surrounded by secrecy and, at the same time, it will ensure that judgments about its morality or abnormality continue to be based on ignorance ${ }^{18}$.

In Mexico, on January 30, 2017, the Supreme Court of Justice of the Nation case-law about family life between same-sex couples, which considers the right same-sex couples have to use scientific advances-derived means to have children, came into force. The Court's criterion, based on considerations of the European Court of Human Rights about the similarity of homosexual and heterosexual couples as regards their capacity to develop a family life, is captured in the following paragraph: "The First Chamber understands that family life between same-sex persons is not solely limited to life as a couple, but that it can extend to the procreation and upbringing of children according to the parents' decision. Hence, there are same-sex couples that make family life with children procreated or adopted by any of them, or couples that use scientific advances-derived means to procreate" 19 . 
Although the Court's criterion does not refer to single persons, but alludes to couples, it will be undoubtedly important to promote equal access to assisted reproduction procedures in Mexico.

Another case where a non-sterile couple might request assisted reproduction treatment and that according to the criteria currently used by both INper and CMN 20 de Noviembre would not be admitted, is the one referred by the same author, Mary Warnock ${ }^{20}$, when any child they are having together has a high percentage of risk of suffering from a serious hereditary disease. Embryos not affected by the disease might be selected to be transferred to the woman's uterus. In this case, the couple would not be able to join the infertility program for not having a sterility diagnosis, but neither would it meet the criterion of being "patients without genetic anomalies susceptible to be inherited by their children" that is established at CMN 20 de Noviembre.

As regards limiting admission to patients without genetic anomalies susceptible to be inherited by their children and that the partner should not have any concomitant disease -criteria established by CMN 20 de Noviembre-, although it is important to consider that reproductive rights legal nature has to be defined by means of a balance between freedom and responsibility, with no doubt the clear limit for them are the rights and needs of born and future children, as well as common $\operatorname{good}^{21}$. However, this criterion is ambiguous and might leave patients defenseless against a possible arbitrary decision by the authorities. For example, what kind of genetic and concomitant diseases?, serious hereditary diseases of possible late onset, or early onset, multifactorial or with variable phenotypic expression? An example would be neurofibromatosis, a disease of variable phenotypic expression characterized by anomalies in the development of muscles, bones and viscera. Having the disease is not dominant for the offspring, and in the assumption its symptoms do develop, it can be serious or not, also depending on multiple factors that will influence throughout the subject's life ${ }^{22}$. And if it was a non-serious genetic disease, susceptible to postnatal curative treatment, would denying access also be justified? If it was some hereditary condition linked to the baby's sex, would couples be offered pre-implantation genetic diagnosis for the detection of specific genetic, structural or chromosomal specific alterations and sex selection in order to prevent transmission of the disease to the offspring, or else resort to gamete or embryo donation? For example, pigmentary retinosis, a condition that might be transmitted to the offspring with a probability of $100 \%$ in case children were from the male sex ${ }^{23}$.
From the medical point of view, in what cases could it really be spoken about the existence of a serious condition that justifies for access to assisted reproduction services to be denied? And what should be understood by serious condition? Who decides which these diseases are and under which criteria? These aspects are important to a moral and legal justification that allows denying access to any HART or to pre-implantation genetic diagnosis ${ }^{24}$.

Finally, at CMN 20 de Noviembre, access is restricted to patients with one child or none, a situation that might collide with the rights to private life and to found a family. Article 4 of our Constitution establishes that every individual has the right to decide in a free, responsible and informed way about the number and spacing of his/her children. The right to reproductive autonomy is also recognized in article 16 (e) of the Convention on the Elimination of All Forms of Discrimination against Women, according to which women have the right "to freely and responsibly decide on the number and spacing of their children and to have access to the information, education and means to enable them to exercise these rights".

As sort of a conclusion of this section, we can say that the lack of specific rules and regulations that standardize human assisted reproduction issues in Mexico promotes that public and private health institutions operate according to internal criteria, which is a situation that generates legal insecurity for both medical personnel and patients. Ingrid Brena ${ }^{25}$ refers on the subject that "it is necessary to insist that not only legislations, but also any decision making -both administrative and legal-, should be based upon scientific information that allows the construction of respectful coexistence directed to an essential objective: respect of human rights involved with reproductive rights".

\section{Informed consent}

Cano Valle ${ }^{26}$ defines informed consent (IC) as "a process that guarantees in writing that, after having received and understood all the necessary and relevant information, the patient has voluntarily expressed his/her intention to participate in any investigation or his/her authorization for diagnostic procedures, medical treatments or surgical interventions of any kind, which entail discomfort, risks or inconveniences that predictably can affect his/her health or dignity, as well as possible alternatives, rights, obligations and responsibilities, to be practiced on him/her".

The informed consent letter, according to the Mexican Official Standard NOM-004-SSA3-2012 (of the 
clinical file $)^{27}$, is defined as the written document, signed by the patient or his/her legal representative or closest relative in bond, by means of which a medical or surgical procedure with diagnostic, therapeutic, rehabilitating, palliative or investigational purposes is accepted, once information on expected risks and benefits for the patient has been received.

\section{Informed consent at INper and CMN 20 de Noviembre}

On this section we will refer to some aspects of the informed consent forms for IVF and embryonic transference (ET) used at INper and CMN 20 de Noviembre. With regard to obtaining the IC from CMN 20 de Noviembre foreign patients, it called our attention that the informed consent form is sent via fax to the users, who will have to hand it over undersigned at the appointment for file opening ${ }^{28}$. In this regard, the NOM004-SSA3-2012 (of the clinical file) establishes that, prior to signing the document, the patient shall receive information about the risks and benefits of the procedure to be carried out. In this case, the treating physician is not observed offering foreign patients sufficient information prior to the signature of the informed consent form.

To obtain the IC, information shall be orally and personally provided; only this way can the users' needs be acknowledged and, consequently, comprehensively offer them sufficient counseling on different possible aspects and implications, as well as on the outcomes and risks the procedures entail. In all cases, the consent procurement shall be a continuous process between the healthcare personnel and the user that, under some assumptions, shall be consolidated in a document ${ }^{29}$.

Another important aspect is the information provided to patients with regard to the number of embryos to be transferred at each assisted reproduction cycle. In this regard, it is fundamental for the medical team to communicate the patient about the maximum number of embryos she may have transferred per cycle, in order to improve the possibilities of pregnancy without jeopardizing her health or increasing the likelihood of multiple pregnancy. However, in the IC form used by INper, the user is not warned about the number of embryos she will have transferred, which is an issue she should be consulted about in order to guarantee her right to choose. Furthermore, at CMN 20 de Noviembre, the IC form specifies that the number of embryos to be transferred will be decided by the medical team in charge, always seeking a balance between the likelihood of pregnancy and multiple pregnancy risk minimization.

With no doubt, there is a need to establish a limit for the number embryos to be transferred; however, the final decision, without exceeding the maximum number of embryos suggested by the medical staff, is the responsibility of the patient. This is owing to the fact that people's values and goals vary, and the best choice is not always the one that prioritizes health, but the one that prioritizes maximum wellbeing according to each individual's values and goals. Therefore, it isn't anymore the doctor the only one who decides the best alternative ${ }^{30}$; the task of the medical team should be to provide the information required by patients and, should there be any bioethical dilemma, consult with the interdisciplinary committee in order to know alternatives or suggestions directed to decision making.

Now, with regard to the consent for the destination of HART supernumerary embryos, the issue is complex, in spite of the fact that, theoretically, these embryos could have three destinations: cryopreservation (for own use), elimination or donation (for healthcare or clinical purposes, investigational or teaching purposes) ${ }^{31}$. In Mexico, since there are no regulations on the use of supernumerary embryos, both at INper and $\mathrm{CMN}$, the only final destination for cryopreserved supernumerary embryos is at this moment for reproductive purposes to be exclusively used by the couple ${ }^{32}$. But in case they decide not to make use of them for their own reproduction, these embryos would remain frozen for indeterminate time ${ }^{33}$. This way, from 2006 to the present day, the CMN 20 de Noviembre assisted reproduction laboratory has 397 cryopreserved supernumerary embryos under its custody; in turn, from 2010 to 2016, INper maintains 657 embryos on cryopeservation $^{34,35}$.

Finally, with regard to information provided to patients on the IVF/ET procedure efficiency in the IC form, both INper and CMN 20 de Noviembre use results obtained in Latin America and reported in the Latin American Registry of Assisted Reproduction as reference ${ }^{36,37}$.

As for HART efficiency, the same informed consent form informs the patients that it is measured as the proportion (rate) of women achieving pregnancy after having embryos transferred to the uterus. Considering that the rate (proportion) of spontaneous abortions is approximately $15-25 \%$, the most real measure to assess efficiency is by measuring the rate of deliveries or live births ${ }^{38,39}$. At this moment, both INper and CMN 
20 de Noviembre have no realistic success estimates in their assisted reproduction programs, owing to the fact that a high percentage of patients who achieve pregnancy with HART do not continue obstetric follow-up at these institutions. In order to offset this issue, INper is planning to implement the use of electronic medical records for patient follow-up ${ }^{40}$. In turn, the CMN 20 de Noviembre Human Reproduction Department, in collaboration with the Department of Planning, is working on the development of indicators to measure the efficiency and quality of service ${ }^{41}$.

\section{Conclusion}

Based on the analysis above, there is an urgent need for Mexican legislative bodies to develop a comprehensive regulation in matters of human assisted reproduction that is respectful of human rights, that guarantees and protects healthcare professionals' activity and promotes the advance of science.

Guidelines have to be established in order for health establishments, both public and private, to conduct their performance with adherence to the law and for fair and equitable access with dignified and quality treatment to be guaranteed.

The destination of healthcare resources and the definition of criteria for the solution of priorities in case excessive demand hinders the satisfaction of all treatment requests are with no doubt a public health problem. However, this does not exempt institutions from making sure that the care and service they provide are compatible with human rights, and from implementing mechanisms that enable an equitable distribution of these services.

On the other hand, IC requirements in matters of assisted reproduction need to be established in order to protect users' rights, making sure they make autonomous, free and informed decisions, and that obtaining the IC is not a mere formal requirement.

Finally, the intervention of Hospital Bioethics and Ethics Committees is fundamental to reach a consensus in decision making, based on the recognition of individual dignity, on patient autonomy, and on the protection of the highest interest of the minor.

\section{References}

1. Bodkin $\mathrm{H}$. Single man will get the right to start a family under new definition of infertility. The Thelegraph, 20 de octubre de 2016. (Consultado el 29 de octubre de 2016.) Disponible en: http://www.telegraph.co.uk/ news/2016/10/19/single-men-will-get-the-right-to-start-a-family-undernew-defini
2. Diagnóstico de la pareja infértil y tratamiento con técnicas de baja complejidad. México: Instituto Mexicano del Seguro Social; 2013. p. 8.

3. Septién González JM. Historia de la ginecología y la obstetricia en México. México: Editorial Ciencia y Cultura de México; 1986. p. 662-5.

4. Cardaci D, Sánchez Bringas A. "Hasta que lo alcancemos..." Producción académica sobre la reproducción asistida en publicaciones mexicanas. Alteridades. 2009;19:24.

5. Palacios C. Una ley que prohíbe embarazos y trasplantes. Animal Político [México], 14 de diciembre de 2016. (Consultado el 16 de diciembre de 2016.) Disponible en: animalpolitico.com/blogueros-una-vida-examinada-reflexiones-bioeticas/2016/12/14/una-propuesta-ley-prohibe-embarazos-trasplantes

6. Sistema de Acceso a la Información Pública: Infomex, folio 1215100132716.

7. Ibidem, folio 1225000012416

8. Ibidem, folio 0064102296416 .

9. Ibidem, folio 1857200288816 .

10. Ibidem, folio 1225000004816 .

11. Ibidem, folio 0063700517416 .

12. Detección y tratamiento integral de la pareja con problemas de infertilidad. Requisitos para obtener el servicio, criterios de aceptación y documentación requerida por trabajo social. Información publicada en el sitio web del INper. (Consultado el 4 de octubre de 2016.) Disponible en: http://www.inper.mx/TramitesRequisitos/ProblemasInfertilidad.html

13. Sistema de Acceso a la Información Pública: Infomex, folio 0063700116616.

14. Corte Interamericana de Derechos Humanos. Caso Artavia Murillo y otros ("Fertilización in vitro") vs Costa Rica, Excepciones Preliminares, Fondo y Reparaciones y Costas, 28 de noviembre de 2012. Disponible en: http://www.corteidh.or.cr/docs/casos/articulos/seriec_257_esp.pdf

15. Langer A. Limitar la reproducción asistida va contra los derechos humanos. El Economista [México], 17 de agosto de 2016. (Consultado el 16 de noviembre de 2016.) Disponible en: http://eleconomista.com.mx/ entretenimiento/2016/08/17/limitar-reproduccion-asistida-va-contra-derechos-humanos

16. Sistema de Acceso a la Información Pública: Infomex, folio: 3510000009316.

17. Recomendación General No. 23/2015 sobre el Matrimonio Igualitario. (Consultado el 15 de octubre de 2016.) Disponible en: http://www.cndh. org.mx/sites/all/doc/Recomendaciones/generales/RecGral_023.pdf

18. Warnock M. Fabricando bebés. ¿Existe un derecho a tener hijos? España: Gedisa; 2004, p. 71, 84.

19. Tesis: 1aJ. 8/2017 (10ª), Semanario Judicial de la Federación, Décima Época, enero de 2017, registro 201353.

20. Warnock M. Op. cit. p. 68.

21. Abellán F. Selección genética de embriones. España: Comares; 2007. p. 147.

22. Ibidem, p. 114-120.

23. Ibidem, p. 125

24. Ibidem, p. 186.

25. Brena Sesma I. La sentencia de la Corte Interamericana de Derechos Humanos, Caso Artavia Murillo y otros (fecundación in vitro) contra Costa Rica. Un avance en el pensamiento laico en Latinoamérica. En: Carbonell Sánchez M, Fix-Fierro HF, Valadés D, coordinadores. Estado constitucional, derechos humanos, justica y vida universitaria. Estudio homenaje a Jorge Carpizo. Derechos Humanos. Tomo V, vol. 1. México: UNAM; 2015. p. 196-7.

26. Cano Valle F. Bioética. Temas humanísticos y jurídicos. México: UNAM; 2005. p. 25.

27. Norma Oficial Mexicana NOM-004-SSA3-2012, del expediente clínico. Diario Oficial de la Federación del 15 de octubre de 2012.

28. Sistema de Acceso a la Información Pública: Infomex, folio: 0063700116616.

29. Guía Nacional para la Integración y el Funcionamiento de los Comités Hospitalarios de Bioética. Secretaría de Salud; 2015. Disponible en: http://www.conbioe<ca-mexico.salud.gob.mx/descargas/pdf/registrocomites/Guia_CHB_Final_Paginada_con_forros.pdf

30. Ibidem, p. 48.

31. Álvarez-Díaz JA. Donación de embriones en países desarrollados. Gac Med Mex. 2010;146:229.

32. Sistema de Acceso a la Información Pública: Infomex, folio: 1225000000617.

33. Ibidem, folio: 0063700028817.

34. Idem.

35. Ibidem, folio: 1225000000617.

36. Ibidem, folio: 1225000004816 .

37. Ibidem, folio: 0063700116616 .

38. Idem.

39. Ibidem, folio: 1225000004816 .

40. Idem.

41. Ibidem, folio: 0063700517416 . 